\title{
Preliminary investigation on use of mushroom to replace beef and turkey for pepper soup
}

\author{
B. A. Akinwande \& A. O. Abegunde \\ Department of Food Science and Engineering, Ladoke Akintola \\ University of Technology (LAUTECH), Ogbomoso, Nigeria
}

\begin{abstract}
Soups have ingredients that are similar to Paleolithic diets. They have potential to provide high unsaturated fatty acids, high $\omega 3 / \omega 6$ ratio of fatty acids, fiber, phytochemical and proteins. Mushroom with its array of health benefits is underutilized in developing countries like Nigeria. In order to popularize and promote its consumption, this research work looked into the possibility of replacing meats with mushroom in pepper soup for enhanced nutrition. Nigerian Pepper soup was prepared with mushroom, beef and turkey. Seasoning and spices were added and the soups were subjected to proximate analysis (on a wet basis) and sensory evaluation using a preference test. There were significant differences $(p<0.05)$ in the proximate composition of the three samples. Crude protein content of chicken pepper soup was highest with a value of $5.20 \%$ and was followed by $3.43 \%$ in mushroom pepper soup. The least value of $2.57 \%$ was obtained in beef soup, while turkey soup had the highest content of crude fat (8.71\%), and mushroom soup recorded with least amount of $1.18 \%$. On the other hand, crude fiber content was highest (5.64\%) in mushroom soup while the least value of $0.79 \%$ was obtained in beef soup. Although the sensory evaluation result showed that the quality attributes of colour, taste, chewiness and tenderness were most preferred in chicken pepper soup, there was no significant difference between it and mushroom soup in all the quality attributes, including aroma and pungency. The use of mushroom could be encouraged to replace meats in the preparation of pepper soup to serve as an anti-inflammatory dietary pattern, which could help to fight diseases related to chronic inflammation, including metabolic syndrome.

Keywords: mushroom, turkey, beef, pepper soup, spice-mix, proximate composition, sensory evaluation, health benefits.
\end{abstract}




\section{Introduction}

Foods eaten by our Paleolithic ancestors promote a balance ratio of omega- 6 and omega-3 fatty acids. Deviation from this led to consumption of modern Western diets that are rich in $\omega 6$ fatty acids, saturated fat and trans fat and low $\omega 3$ fatty acids, fiber, phytoestrogens, minerals and antioxidants [1-3]. This led to increase in an ageing population, central obesity, excessive salt, lower fruit, vegetable and legumes intake, hypertension, type 2 diabetes, atherosclerosis, and some cancers [4]. Spices have been used as flavoring and coloring agents from time immemorial. Documented experimental research indicate their therapeutic effects such as hypolipidemic, hypocholeserolemic, antilithogenic effect, antidiabetic potential, digestive stimulant action, antioxidant property, antiinflammatory properties, anti-mutagenic and anti-carcinogenic property, and antimicrobial [5].

Nigerian Pepper Soup is a spicy, intensely flavored and aromatic broth like soup made primarily from blend of several aromatic native spices and excess water, to which cuts of meat of choice are always added. Categories of meat that are used are beef, mutton, lamb, offal, processed cattle skin, skinned oxtail, cow leg, chicken, turkey and fish. Pepper soup is eaten year round in Nigeria, despite the hot weather. It is served in most local restaurants and hotels and can be eaten alone as a low-carbohydrate dish. It is also eaten with white rice and boiled yam.

Mushrooms as food are valued for their low calories and high minerals, essential amino acids, vitamins and fiber contents [6]. Wild edible mushroom are good sources of essential micro-nutrients like $\mathrm{Mg}, \mathrm{Mn}, \mathrm{Cu}, \mathrm{Fe}$ and $\mathrm{Zn}$ [7]. Many cultures use them for nutrition and health benefits but their use for therapeutic purpose has long been established in Asian countries. Several reports on the medicinal properties of mushrooms such as antitumor, anti-inflammatory, antiviral, antibacterial, hepatoprotective, antidiabetic and immunomodulatory activities have been reviewed [8]. Oyster mushroom supplemented diet has positive effect on the atherogenic lipid profile [9].

There is global shift to positive eating habit. Nowadays, consumers balance health concerns with pleasurable eating. More often, it is now about real food and the ability to provide nutrients and health benefits naturally when it has to do with delivering health and wellness [10]. Included as part of the ten functional food trends are: real food nutrition; effectiveness of nutrients to deliver highly desirable health benefits; protein power; plant-based diets; increase in the market for heart-healthy products; and use of natural solutions to common everyday ailments.

Good nutrition is a basic human right. In order to have a healthy population that can promote development, the relation between food, nutrition and health should be reinforced. In developing countries like Nigeria, this can be achieved through the exploitation of available local underutilized functional food crops such that the needs of the population can be satisfied.

Wild edible mushrooms are currently marketed in urban centers and major highways during raining season in Nigeria. Cost of such is still cheaper than meat from animal sources that they have tendency to replace in terms of 
nutrients. There is an improvement in acceptance of mushroom as food in urban centers in Nigeria compared to the past when consumption was only by rural dwellers. There is also shift from total dependence on wild harvest of mushroom to cultivation of different strains of tropical mushroom species. Despite all these, consumption of this readily available functional food is still far below expectation in Nigeria. Some cultivation centers fold up due to lack of patronage. It is important to look into the possibilities of enhancing the utilization of health beneficial mushroom through different diets, especially for maintenance of good health. One of the ways to do this is to establish the nutritional value and acceptability of the diet to be introduced.

The aim of the present study was to carry out preliminary investigation on whether it could be possible to replace oyster mushroom with turkey meat and beef, which have saturated fats, in production of Nigerian pepper soup. Information on this is necessary to encourage increase in consumption and cultivation of this functional food crop. Proximate components as well as sensory quality attributes (using acceptability test) of the soup samples were evaluated.

\section{Materials and methods}

Freshly harvested cultivated oyster mushroom (Pleurotus sajor-caju) was obtained from Forestry Research Institute of Nigeria (FRIN), Ibadan, Nigeria. Traditional aromatic pepper soup spice-mix (prepared by the market women) and seasonings were purchased from open market in Ibadan, Nigeria. Boneless turkey and beef cuts from lap and thigh, respectively, were obtained from open market in Ogbomoso town. All fresh materials were used on the day of purchase.

\subsection{Pepper soup preparation}

Turkey and beef (500 g each) were rinsed with portable water; each was cut into cubes of about $1 \mathrm{~cm}$ and transferred into separate pots. Into each of the pots were added 2 cubes of seasoning, $4 \mathrm{~g}$ of iodized table salt, and $1 \mathrm{~L}$ water and the contents were allowed to boil over medium heat for $30 \mathrm{~min}$ to allow the meat to tenderize. The volume of the broth was made up to $2 \mathrm{~L}$ with water thereafter and 4 spoonfuls of spice-mix was added with the additional 2 cubes of seasoning. The contents were allowed to cook for 35 min.

Reduced quantity (250 g) of mushroom was used. It was discovered from trial experiment that mushroom requires more quantity of water to cook than meat. The dirty ends of the mushroom stems were trimmed off before being transferred inside bowl of portable water, swished around until the dirt comes off and were subsequently rinsed. They were then transferred into colander to allow draining of water. Size of the mushrooms was reduced by cutting the cap into squares of about $1.3 \mathrm{~cm}$ while the stalk was also cut into thickness of $1 \mathrm{~cm}$ and the pieces were transferred into pot. Four cubes of seasoning, 4 spoonfuls of spice-mix, $4 \mathrm{~g}$ of iodized table salt, and $2 \mathrm{~L}$ water were later added and the content was allowed to cook over medium heat for $35 \mathrm{~min}$. 


\subsection{Sensory evaluation}

Soup samples were served in disposable plastic containers with three digit code numbers at lukewarm temperature. Samples at each session were presented in duplicates. Sensory evaluation was carried out using acceptability test with untrained in-house panel consisting of 50 members that were familiar with Nigerian pepper soup. Panelists were provided with water to rinse their mouth during the evaluation. Each sample was assessed for the quality attributes considered: colour, taste, aroma, chewiness, tenderness, and pungency. Seven level hedonic scale of assessment was used for evaluating the quality attributes: 7 represented like extremely, 6 for like moderately, 5 for like slightly, 4 for neither like nor dislike, 3 for dislike slightly, 2 for dislike moderately, and 1 represented dislike extremely.

\subsection{Proximate composition analysis}

A quarter of the quantity prepared for sensory evaluation was prepared again for proximate analysis. However, equal quantity of mushroom was used with other meats. Samples were homogenized in a food blender for about five minutes at the medium speed setting available on the blender. The proximate composition of the homogenized pepper soup samples were determined by standard methods [11]. Crude protein was calculated by $\mathrm{N}$ x 6.25. Carbohydrate content was obtained by difference.

\subsection{Statistical analysis}

The data generated from all the experiments in three replicates were subjected to statistical analysis using SAS package (version 9.2 of SAS institute Inc, 2002). Statistically significant differences $(p \leq 0.05)$ in all data were determined by Analysis of variance (ANOVA) procedure while Least Significant Difference (LSD) was used to separate the means.

\section{Results and discussion}

The results of the proximate composition of pepper soup samples made from turkey meat, beef and mushroom are presented in Table 1 . There were variations in the values obtained in the three sample with significant difference $(p<0.05)$. The sample containing turkey had highest crude protein content $(5.20 \%)$ and is followed by pepper soup made with mushroom. Least value of $2.57 \%$ was obtained in the sample containing beef. Higher protein content of mushroom pepper soup than beef pepper soup is as a result of high protein content (37.4\%) of Pleurotus sajor-caju [12]. Highest fat content (8.71\%) was recorded in turkey pepper soup while least value of $1.18 \%$ was obtained in mushroom pepper soup.

Highest and least values of $5.64 \%$ and $0.79 \%$ were obtained for crude fiber in mushroom and beef pepper soup samples, respectively. High value of crude fiber in mushroom could be responsible for requirement for more water, than other meats, during the preparation of soup for sensory evaluation. Water-holding 
capacity of oyster mushroom is significantly higher than wheat bran [13]. This was explained to be related to the presence of semi-pure glucomanan. Crude fiber content of turkey and beef pepper soup is a result of the spice-mix that was used since crude fiber in beef and turkey meat are below detection limit [14]. Dietary fiber is undoubtedly one of the most talked about nutrients for health promotion and disease prevention. Consumption of pepper soup especially that made with mushroom will be good for health promotion and disease prevention.

Means for sensory scores of pepper soup samples are shown in Table 2. There was no significant difference $(p<0.05)$ in the ratings for colour in all the pepper soup samples. Highest rating for taste (6.71) was obtained for turkey pepper soup. While the rating for taste in mushroom pepper soup is not significantly different from turkey pepper soup, it is significantly higher than that of beef pepper soup. Value obtained for aroma in mushroom pepper soup is not significantly different from the remaining two samples. In terms of chewiness and tenderness, all the samples were not significantly different from one another. However, least value was obtained for chewiness and tenderness in mushroom pepper soup. The implication of this is that the time that was used to cook the mushroom was too much and there is need to reduce the timing. Considering the pungency, rating for feeling for pepper was highest in mushroom pepper soup (5.64), but with no significant difference from others. This means that beef is able to suppress the effect of pepper in soup, followed by turkey meat.

Table 1: $\quad$ Proximate composition (\%) of pepper soup samples (wet basis).

\begin{tabular}{|c|c|c|c|c|c|c|}
\hline Soup & $\begin{array}{c}\text { Crude } \\
\text { protein } \\
\text { content }\end{array}$ & $\begin{array}{c}\text { Crude } \\
\text { fat } \\
\text { content }\end{array}$ & $\begin{array}{c}\text { Crude } \\
\text { fiber } \\
\text { content }\end{array}$ & $\begin{array}{c}\text { Ash } \\
\text { content }\end{array}$ & $\begin{array}{c}\text { Moisture } \\
\text { content }\end{array}$ & $\begin{array}{c}\text { Carbohydrate } \\
\text { content }\end{array}$ \\
\hline Turkey & $5.20 \mathrm{a}$ & $8.71 \mathrm{a}$ & $1.36 \mathrm{~b}$ & $2.74 \mathrm{a}$ & $80.65 \mathrm{~b}$ & $1.34 \mathrm{c}$ \\
\hline Mushroom & $3.43 \mathrm{~b}$ & $1.18 \mathrm{c}$ & $5.64 \mathrm{a}$ & $1.50 \mathrm{c}$ & $86.54 \mathrm{a}$ & $1.71 \mathrm{~b}$ \\
\hline Beef & $2.57 \mathrm{c}$ & $1.97 \mathrm{~b}$ & $0.79 \mathrm{c}$ & $4.51 \mathrm{~b}$ & $86.13 \mathrm{a}$ & $4.03 \mathrm{a}$ \\
\hline
\end{tabular}

Means followed by the different letters along the column are significantly different $(p<0.05)$.

Table 2: $\quad$ Mean scores for sensory quality attributes of pepper soup.

\begin{tabular}{|c|c|c|c|c|c|c|}
\hline Soup & \multicolumn{6}{|c|}{$*$ Quality attributes } \\
\hline & Colour & Taste & Aroma & Chewiness & Tenderness & Pungency \\
\hline Turkey & $5.86 \mathrm{a}$ & $6.21 \mathrm{a}$ & $5.71 \mathrm{a}$ & $5.71 \mathrm{a}$ & $5.86 \mathrm{a}$ & $5.57 \mathrm{a}$ \\
\hline Mushroom & $5.57 \mathrm{a}$ & $5.79 \mathrm{a}$ & $5.14 \mathrm{ab}$ & $5.29 \mathrm{a}$ & $4.86 \mathrm{a}$ & $5.64 \mathrm{a}$ \\
\hline Beef & $5.86 \mathrm{a}$ & $4.79 \mathrm{~b}$ & $5.79 \mathrm{~b}$ & $5.50 \mathrm{a}$ & $5.43 \mathrm{a}$ & $5.07 \mathrm{a}$ \\
\hline
\end{tabular}

Means followed by the different letters along the column are significantly different $(p<0.05)$ from one another.

*Hedonic ratings: 7 = Like extremely; 6 = Like moderately: 5 = Like slightly; 4 = Neither like nor dislike; 3 = Dislike slightly; 2 = Dislike moderately; $1=$ Dislike extremely. 


\section{Conclusion}

Mushroom pepper soup has a higher protein content, compared to beef pepper soup, and the highest amount of crude fiber compared to that made from turkey meat and beef. It also has the advantage of having the least content of crude fat compared to the other two samples. While the preference for taste in mushroom pepper soup is not significantly different from that of turkey pepper soup, it is significantly higher than that of beef pepper soup.

Mushroom could thus be used to replace meat in Nigerian pepper soup. Utilization of mushrooms in this form may contribute significantly in overcoming protein deficiency. It will also serve as an anti-inflammatory dietary pattern, which could help to fight diseases related to chronic inflammation, including metabolic syndrome in developing countries like Nigeria. There is need to enlighten the populace on need to consider consumption of mushroom pepper soup based on its high crude protein and fiber contents, as well as other biological active substances that have medicinal value. This will make it possible to eat diet which provides nutrients and health benefits naturally.

\section{References}

[1] Simopoulos, A.P., Importance of the ratio of omega-6/omega-3 essential fatty acids: evolutionary aspects. Omega-6/omega-3 essential fatty acid ratio: the scientific evidence. World review of nutrition and dietetics, eds. A.P. Simopoulos and L.G. Cleland, Karga Publishers: Basel, pp. 1-19, 2003.

[2] Katcher, H.I., Legro, R.S., Kunselman, A.R., Gillies, P.J., Demers, L.M., Bagshaw, D.M. and Kris-Etherton, P.M., The effects of whole grainenriched hypocaloric diet on cardiovascular disease risk factors in men and women with metabolic syndrome. American Journal of Clinical Nutrition, 87, pp. 79-90, 2008.

[3] de Meester, F., Wild-type land based food in health promotion and disease prevention, the Columbus Concept. Wild type food in health promotion and disease prevention, eds. F. de Meester and R.R. Watson, Humana Press: Totova, NJ, pp. 3-20, 2008.

[4] Singh, R.B., Fedacko, J., Pella, D., Macejova, Z., Ghosh, S., de Amit, K., Begom, R., Tumbis, Z.A., Haque, M., Vajpeyee, S.K., de Meester, F., Sergey, C., Agarwalo, R., Muthusamy, V.V., Five City Study Group and Gupta, A.K., Prevalence and risk factors of prehypertension and hypertension in five Indian cities. Acta Cardiologica, 66(1), pp. 29-37, 2011.

[5] Bhandari, M.R. and Bhantarai, U.K., Spices: As a functional food with multiple health benefits. ネパールにおける機械工学教育 Vol.9, 2007.

[6] Mattila, P., Salo-Vaananen, P., Konko, K., Aro, H. and Jalava, T., Basic composition and amino acid contents of mushrooms cultivated in Finland. Journal of Agricultural and Food Chemistry, 50, pp. 6419-6422, 2002. 
[7] Akinwande, B.A., Determination of chemical composition and trace and heavy metals in wild edible mushroom samples from Ogbomoso, Nigeria. LAUTECH Journal of Engineering and Technology (LAUJET), 6(2), pp. 53-56, 2011.

[8] Lindequist, U., Niedermeyer, T.H.J. and Jülich, W.D., The pharmacological potential of mushrooms. eCAM, 2, pp. 285-99, 2005.

[9] Yoon, K.N., Alam, N. and Lee, T.S., Hypolipidemic and antiatherogenesis effect of culinary-medicinal pink oyster mushroom, Pleurotus salmoneostramineus L. Vass. (higher Basidiomycetes), in hypercholesterolemic rats. International Journal of medicinal mushrooms, 14(1), pp. 27-36, 2012.

[10] Sloan, A.E., Top 10 functional food trends. Food Technology Monthly newsletter, April 2012, pp. 24-43.

[11] A.O.A.C., Official Methods of Analysis (15 ${ }^{\text {th }}$ edition). Association of Official Analytical Chemists, Washington D.C., 2000.

[12] Akyüz, M. and Kirbag, S., Nutritive value of wild edible and cultured mushrooms. Turkish Journal of Biology, 34, pp. 97-102, 2010.

[13] Moharram, H.A., Salama, M.F. and Hussien, A.A., Characterization of Oyster Mushroom Mycelia as a Food Supplement. Australian Journal of Basic and Applied Sciences, 2(3), pp. 632-642, 2008.

[14] Wardlaw, G.M., Hampl, J.S. and Disilvestro, R.A., Perspectives in Nutrition, sixth edition, McGraw-Hill: New York, pp. A-160-A-164, 2004. 